\title{
CLINICAL AND LABORATORIAL STUDY OF 19 CASES OF MUCOPOLYSACCHARIDOSES
}

Lilian M. J. Albano, Sofia S. M. M. Sugayama, Débora R. Bertola, Carlos E. F. Andrade, Cláudia Y. Utagawa, Flávia Puppi, Helena B. Nader, Leny Toma , Janice Coelho, Sandra Leistner, Maira Burin , Roberto Giugliani and Chong A. Kim

ALBANO LMJ et al. - Clinical and laboratorial study of 19 cases of mucopolysaccharidoses. Rev. Hosp. Clín. Fac. Med. S. Paulo 55(6):213-218, 2000

The mucopolysaccharidoses (MPS) are a heterogeneous group of inborn errors of lysosomal glycosaminoglycan (GAG) metabolism. The importance of this group of disorders among the inborn errors of metabolism led us to report 19 cases.

Method: We performed clinical, radiological, and biochemical evaluations of the suspected patients, which allowed us to establish a definite diagnosis in 19 cases.

Results: Not all patients showed increased GAG levels in urine; enzyme assays should be performed in all cases with strong clinical suspicion. The diagnosis was made on average at the age of 48 months, and the 19 MPS cases, after a full clinical, radiological, and biochemical study, were classified as follows: Hurler - MPS I (1 case); Hunter - MPS II (2 cases); Sanfilippo - MPS III (2 cases); Morquio - MPS IV (4 cases); Maroteaux-Lamy - MPS VI (9 cases); and Sly - MPS VII (1 case).

Discussion: The high relative frequency of Maroteaux-Lamy disease contrasts with most reports in the literature and could express a population variability.

DESCRIPTORS: Mucopolysaccharidoses. Glycosaminoglycans. Lysosomal storage diseases.

The mucopolysaccharidoses (MPS) are a heterogeneous group of lysosomal storage disorders caused by the deficiency of enzymes involved in degradation of glycosaminoglycans, also named mucopolysaccharides. Its pattern of inheritance is autosomal recessive, except for MPS II, which is Xlinked. The incidence of MPS may be as high as 1:10 000 live births, and Hurler syndrome is usually reported in the literature as the most frequently occurring type $\mathrm{e}^{1,2}$.

There are at least 10 enzymes known to be required for the stepwise degradation of dermatan sulfate, heparan sulfate, keratan sulfate, and chondroitin sulfate, deficiencies of which lead to a wide spectrum of a progressive and chronic clinical disorders (Table 1).

The importance of this group of disorders among the inborn errors of metabolism led us to report 19 MPS cases after clinical, radiological, and biochemical investigations, which allowed us to establish the definitive diagnosis.

From the Genetic Unit of the Department of Pediatrics, Hospital das Clínicas, Faculty of Medicine, University of São Paulo; Biochemistry Department of UNIFESP and Department of Genetics, Hospital de Clínicas, Porto Alegre.

\section{PATIENTS AND METHODS}

The study was carried out over a period of six years (1994-1999). We could establish the definitive diagnosis, including the specific type of MPS, in 19 patients

The main features observed were: normal appearance at birth with a progressive coarse facies, progressive neurological deterioration, corneal clouding, gibbous lumbar vertebrae, hirsutism, joint contractures, hepatosplenomegaly, short stature, and skeletal, respiratory, and cardiac abnormalities, with a characteristic pattern of a chronic and progressive disorder. Radiological and ophthalmologic studies 
Table 1 - Classification of the mucopolysaccharidoses.

\begin{tabular}{lll}
\hline MPS TYPE & EPONYM & ENZYME DEFECT \\
\hline I & Hurler & $\alpha$-L-iduronidase \\
II & Hunter & Iduronate 2-sulfatase \\
III-A & Sanfilippo type A & Heparan N-sulfatase \\
III-B & Sanfilippo type B & $\alpha$-N-acetylglucosaminidase \\
III-C & Sanfilippo type C & Acetyl-CoA: $\alpha$ glucosaminide N-acetyltransferase \\
III-D & Sanfilippo type D & N-acetylglucosamine 6-sulfatase \\
IV-A & Morquio type A & Galactose 6-sulfatase \\
IV-B & Morquio type B & $\beta$-galactosidase \\
VI & Maroteaux-Lamy & N-acetylgalactosamine 4-sulfatase \\
VII & Sly & $\beta$-glucuronidase \\
\hline
\end{tabular}

were indicated for all patients suspected.

A biochemical investigation was carried out according to the proposal of Leistner and Giugliani ${ }^{3}$, in suspected patients. Initially, the glycosaminoglycan (GAG) concentration in urine was measured, and the relative proportion of their components (dermatan sulfate, heparan sulfate, chondroitin sulfate, and keratan sulfate) was estimated.

The diagnostic enzyme assays were selected according to clinical suspicion and results of the biochemical investigation.

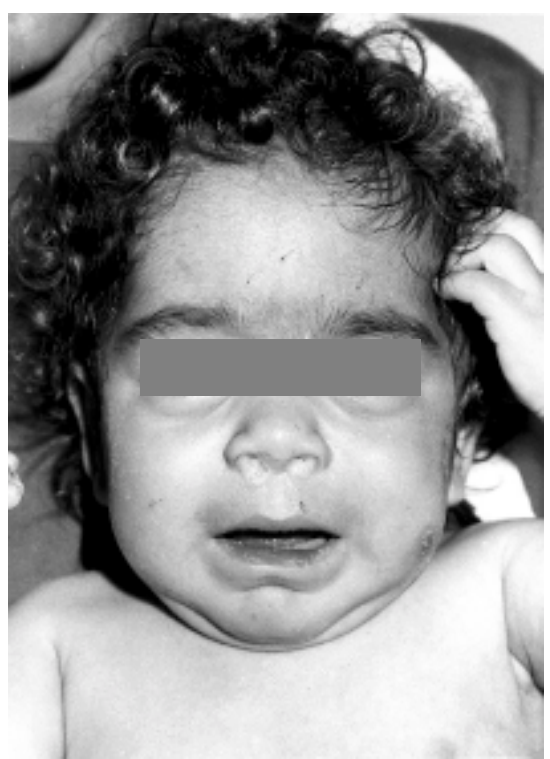

\section{RESULTS}

The biochemical investigation allowed the diagnosis of 19 MPS cases, classified as follows: Hurler - MPS I (1 case $-5.3 \%)$; Hunter - MPS II (2 cases $-10.5 \%)$; Sanfilippo - MPS III ( 2 cases $-10.5 \%$; all type B); Morquio - MPS IV (4 cases - $21.1 \%$; all type A); Maroteaux-Lamy - MPS VI (9 cases $-47.4 \%)$ and Sly - MPS VII (1 case $-5.3 \%$ ) (Fig. 1-5).

The average age at diagnosis was 48 months (ranging from 7 to 19 years), and the patients' ages ranged from 2 to 20 years.

Parental consanguinity was observed in 6 cases. Thirteen cases were sporadic, being the reminiscent familial.

Most patients presented coarse facial features $(16 / 19-84 \%)$ and hepatosplenomegaly $(12 / 19-63 \%)$. The frequency of obstructive airway disease was 53\%, and corneal clouding was observed in $37 \%$; gibbous lumbar vertebrae occurred in $58 \%$ of the cases, and joint stiffness occurred in $74 \%$.

Cardiac abnormalities were observed in 9 cases (47\%), including cardiac murmur (4/9 - 44\%), mitral and tricuspid valvar reflux $(2 / 9-22 \%)$, and septal defects $(2 / 9-22 \%)$. A pericardium effusion $(1 / 9-11 \%)$ was observed in 1 case of Hurler syndrome.

Skeletal abnormalities were evident in 16 out of 18 cases radiologically studied (89\%). We found the following main radiological findings: "J-shaped" sella turcica, dorsal kyphosis, broad and saber-shaped ribs, wedge-shaped beaking abnormality of the vertebral body, osteoporosis, increased diameter of tubular bones, angulation of the distal end of the radius and ulna, narrowing of the proximal metacarpals, delayed carpal bone age, and hip abnor-

Figure 1 - MPS patient: Type I (1y). 

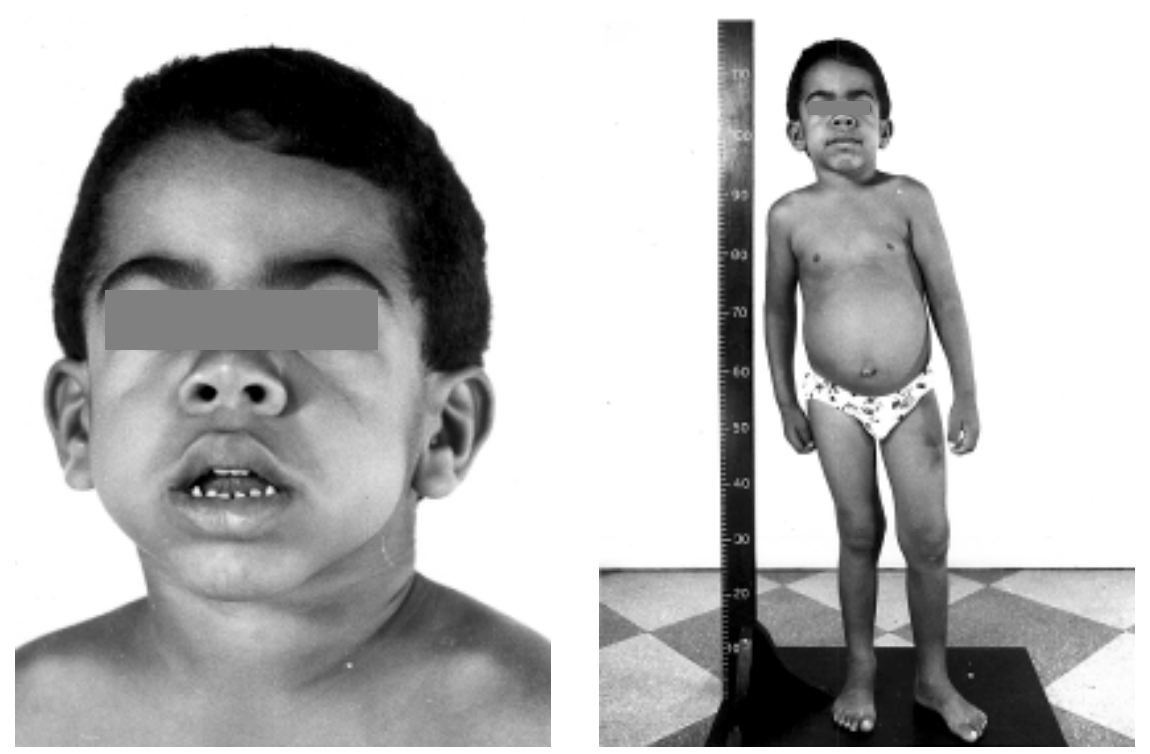

Figure 2 - MPS patient: Type II (5y).
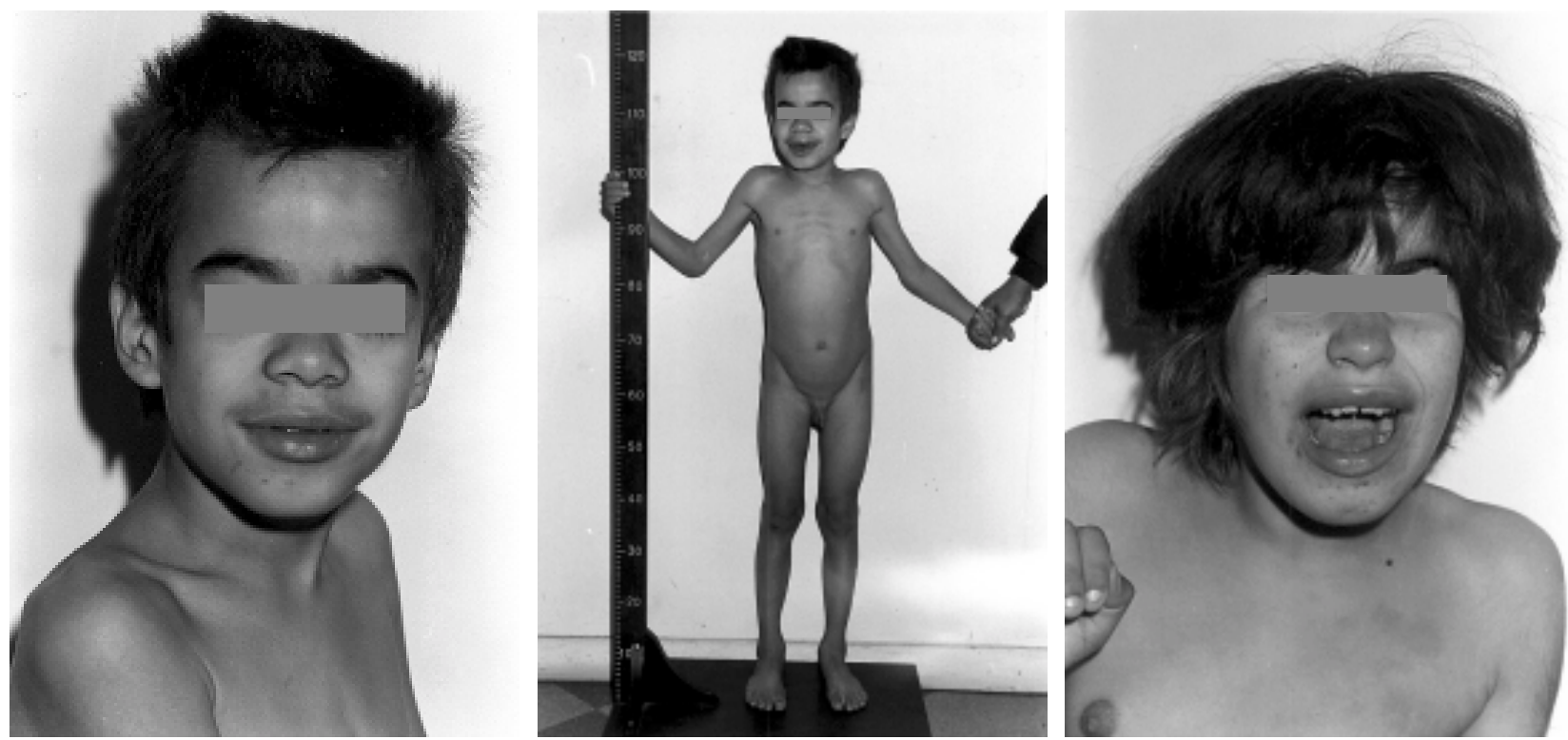

Figure 3 - Two brothers with MPS type III-B (8y,13y).
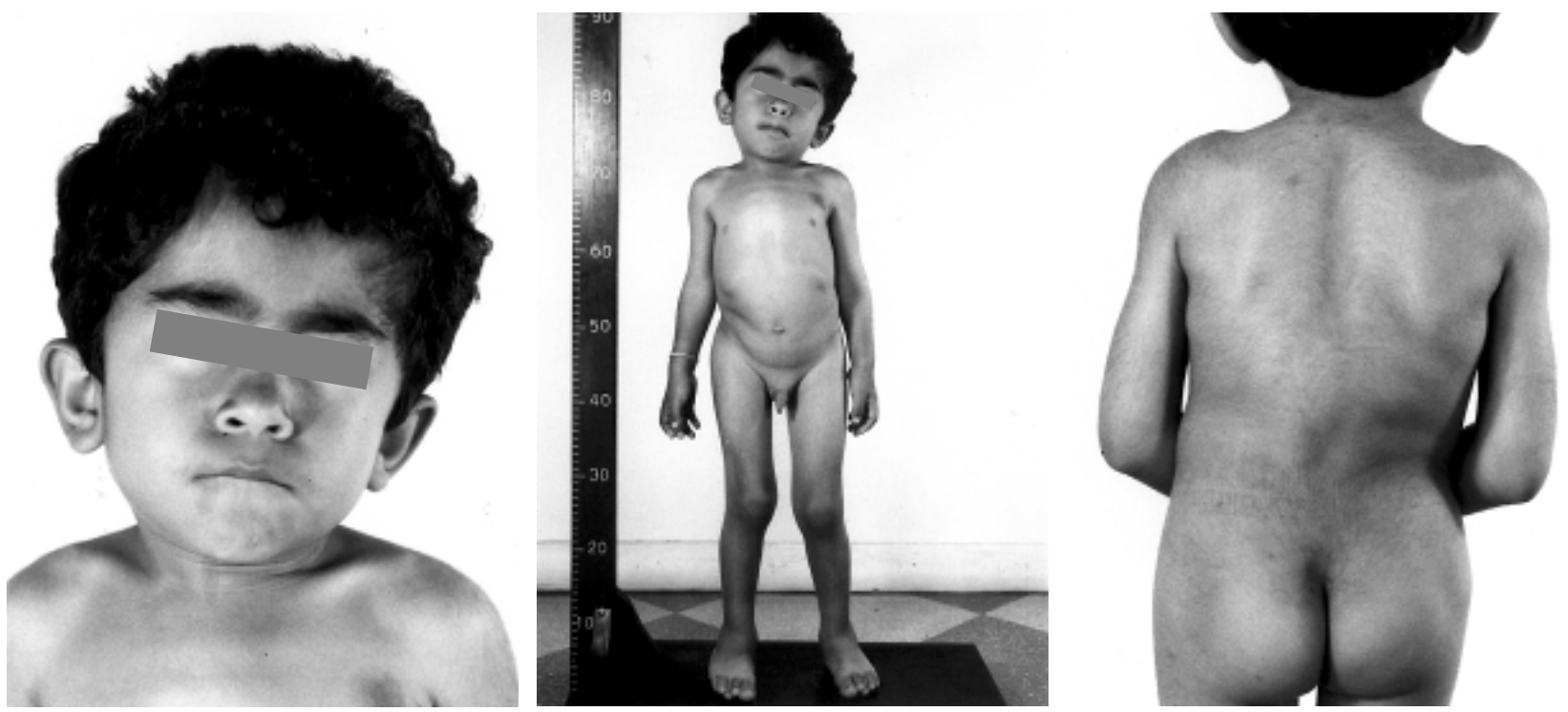

Figure 4 - MPS patient: Type IV-A (4y). 

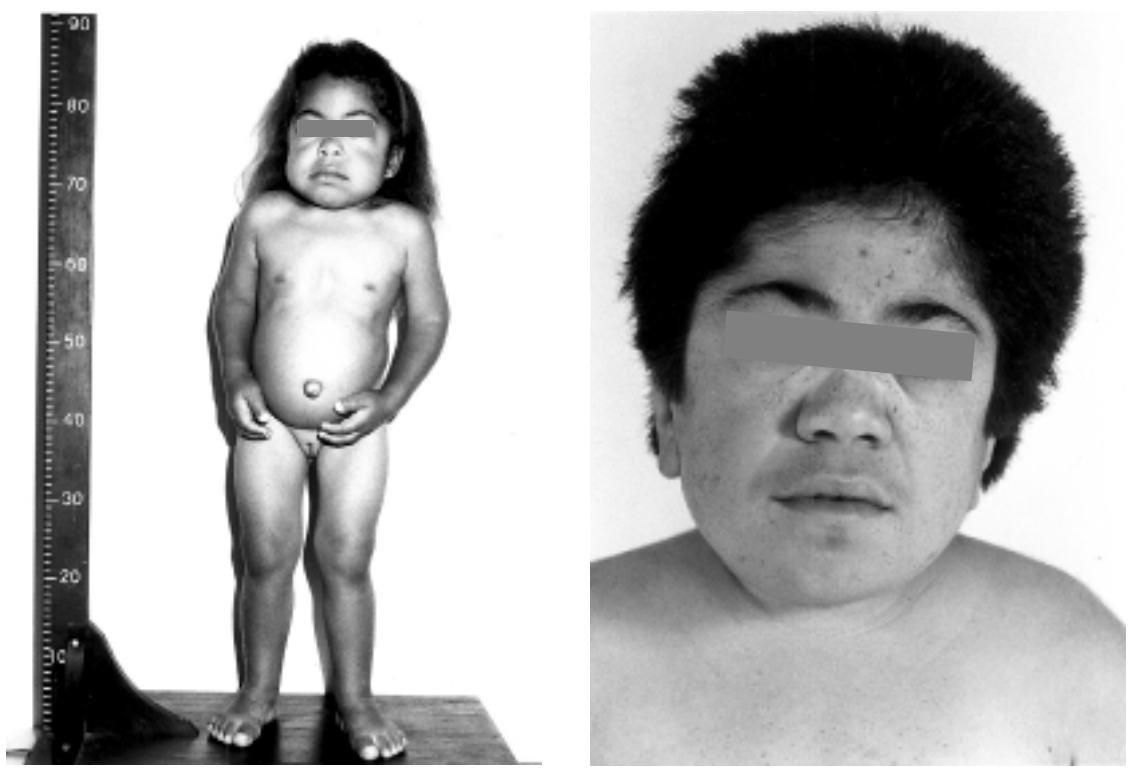

Figure 5 - MPS patients: Type VI (5y,17y).

malities as a constriction above the acetabulum.

Developmental delay, a feature present in $42 \%$ of the cases (8/19), was observed in the Hurler, Hunter, and
Sanfilippo cases, and also in 2 Maroteaux-Lamy cases.

The clinical, radiological, and biochemical results are summarized in table 2.

\section{DISCUSSION}

The most frequent type of MPS is reported to be Hurler syndrome (MPS type I) with an estimated frequency of 1:50 000 to $1: 132000^{1,4,5,6,7}$. This figure is probably underestimated, due to early deaths and diagnostic difficulties. Hunter syndrome is also reported to be frequent, but with lower incidence than Hurler syndrome. The clinical frequency of Morquio syndrome seems to be lower than that of Hurler and Hunter syndromes ${ }^{4}$.

Sanfilippo syndrome ranks among the most common types of MPS ${ }^{1}$. As there are not striking physical features accompanying the marked mental retardation of the Sanfilippo syndrome, Neulfeld and Muenzer $(1995)^{2}$ believe that it is under diagnosed, considering the high incidence found in the Netherlands (1:24 000 live births) as a result of the efforts employed to detect all cases.

Table 2 - Clinical, laboratory and radiologic findings in 19 patients.

\begin{tabular}{|c|c|c|c|c|c|c|c|c|c|c|c|c|c|}
\hline Type & & SS & MD & Coarse & $\mathrm{CO}$ & Visc & Gib & JS & Hirs & Card & Skel & GAGS & Enzymatic defect \\
\hline I & Hurler & + & + & + & + & $\mathrm{H} / \mathrm{S}$ & + & + & + & + & + & $\uparrow$ & $\alpha$-L-iduronidase \\
\hline II & Hunter & - & + & + & - & $\mathrm{H}$ & - & + & + & - & + & $\uparrow$ & Iduraonate 2-sulfatase \\
\hline II & Hunter & + & + & + & - & $\mathrm{H} / \mathrm{S}$ & + & + & + & + & + & $\uparrow$ & Iduraonate 2-sulfatase \\
\hline III-B & Sanfilippo & - & + & + & - & $\mathrm{H} / \mathrm{S}$ & - & - & - & - & - & normal & $\alpha-\mathrm{N}$-acetylglucosaminidase \\
\hline III-B & Sanfilippo & - & + & + & - & $\mathrm{H} / \mathrm{S}$ & - & - & - & - & - & $\S$ & $\alpha$-N-acetylglucosaminidase \\
\hline IV-A & Morquio & - & - & + & + & - & + & - & - & + & + & $\uparrow$ & Galactose 6-sulfatase \\
\hline IV-A & Morquio & + & - & - & - & - & - & + & - & - & + & normal & Galactose 6-sulfatase \\
\hline IV-A & Morquio & + & - & - & - & - & - & + & - & - & + & normal & Galactose 6-sulfatase \\
\hline IV-A & Morquio & + & - & - & - & - & + & - & - & - & + & normal & Galactose 6-sulfatase \\
\hline VI & Maroteaux-Lamy & + & - & + & - & $\mathrm{H} / \mathrm{S}$ & + & + & + & + & + & $\uparrow$ & $\mathrm{N}$-acetylgalactosamine sulfatase \\
\hline VI & Maroteaux-Lamy & + & - & + & - & $\mathrm{H} / \mathrm{S}$ & - & + & + & + & + & $\uparrow$ & $\mathrm{N}$-acetylgalactosamine ulfatase \\
\hline VI & Maroteaux-Lamy & + & - & + & - & $\mathrm{H} / \mathrm{S}$ & + & + & + & + & + & $\uparrow$ & $\mathrm{N}$-acetylgalactosamine sulfatase \\
\hline VI & Maroteaux-Lamy & + & - & + & + & $\mathrm{H} / \mathrm{S}$ & + & + & + & - & + & Normal & $\mathrm{N}$-acetylgalactosamine sulfatase \\
\hline VI & Maroteaux-Lamy & - & + & + & + & $\mathrm{H} / \mathrm{S}$ & + & + & + & - & + & $\uparrow$ & $\mathrm{N}$-acetylgalactosamine sulfatase \\
\hline VI & Maroteaux-Lamy & - & + & + & + & $\mathrm{H} / \mathrm{S}$ & + & + & + & - & + & $\uparrow$ & $\mathrm{N}$-acetylgalactosamine sulfatase \\
\hline VI & Maroteaux-Lamy & + & - & + & + & $\mathrm{H} / \mathrm{S}$ & - & + & + & + & + & $\uparrow$ & $\mathrm{N}$-acetylgalactosamine sulfatase \\
\hline VI & Maroteaux-Lamy & + & - & + & + & - & + & + & + & + & + & $\uparrow$ & $\mathrm{N}$-acetylgalactosamine sulfatase \\
\hline VI & Maroteaux-Lamy & - & - & + & - & $\mathrm{H} / \mathrm{S}$ & + & + & + & + & + & $\uparrow$ & $\mathrm{N}$-acetylgalactosamine sulfatase \\
\hline VII & Sly & + & + & + & - & $\mathrm{H} / \mathrm{S}$ & - & - & - & - & $\S$ & $\S$ & $\beta$-glucuronidase \\
\hline
\end{tabular}

Abrev: SS = short stature; $\mathbf{M D}=$ mental delay; Coarse = Coarse facies $; \mathbf{C O}=$ Corneal opacity; Visc = visceromegaly $;$ Gib = gibbous vertebrae; $\mathbf{J S}=$ joint stiffness; Hirs = hirsutism; Card = cardiac abnormalities; Skel = skeletal abnormalities; $\$=$ not performed. $\mathrm{H} / \mathrm{S}=$ Hepatomegaly/Splenomegaly 
MPS type VI, known as Maroteaux-Lamy syndrome, does not have good estimates of its frequency, as it seems to be rare in most reports and as a considerable number of individuals with Hurler-Scheie syndrome were classified in the past as having Maroteaux-Lamy syndrome ${ }^{1}$.

Our results, in contrast to the literature ${ }^{1,4,5,6,7,8,9}$, show a high proportion of Maroteaux-Lamy cases (47\%). As there are few reports about MPS incidence in Brazil ${ }^{10,11}$, we believe that this significant proportion of MPS VI cases could be caused by population characteristics.

Our clinical investigation (Table 2) revealed short stature in 12/19 cases $(63 \%)$ and normal growth in 7 patients: 1/2 Hunter; 2/2 Sanfilippo; 1/4 Morquio; 3/9 Maroteaux-Lamy. The finding of abnormalities in the skeletal evaluation was the most consistent finding in all MPS types: 16/18 cases (88\%), sparing only the 2 Sanfilippo patients.

Coarse facies was observed in 16/ 19 cases (84\%), (the exceptions were three Morquio patients). Hepatosplenomegaly was detected in 14/19 cases $(73 \%)$, not being found in 1 Maroteaux-Lamy case and in the 4 Morquio patients. Corneal opacity was observed in 7/19 cases (36\%), and cardiac involvement was observed in 9/19 patients $(47 \%)$.

Mental retardation was present in 8/ 19 cases $(42 \%)$. Normal intelligence was present in all Morquio patients and 7/9 Maroteaux-Lamy cases (77\%).

Clinical and radiological findings are fundamental for the diagnosis of a
MPS disorder. However, investigation of glycosaminoglycans and enzymatic studies are essential not only to establish the definitive diagnosis but also to classify exactly the MPS type - information very useful for genetic counseling and prenatal diagnosis.

The finding of normal urinary GAG levels in $5 / 17$ patients $(29 \%)$ is an indication that a normal urinary GAG pattern does not rule out the possibility of a MPS disorder.

Diagnosis is not always easy, and confirmation is based on specific enzymatic investigation. Therefore, both physicians and laboratory personnel should contribute their experience to a complete study of cases with a suspected MPS disorder, in order to conduct a rapid and through investigation to reach an accurate diagnosis.
ALBANO LMJ e col. - Estudo clínico e laboratorial de 19 casos de mucopolissacaridoses. Rev. Hosp. Clín. Fac. Med. S. Paulo 55(6): 213-218, 2000.

As mucopolissacaridoses (MPS) constituem um grupo de erros inatos do metabolismo lisossomal dos glicosaminoglicanos (GAG) bastante heterogêneo. A importância das MPS levou-nos a relatar as características de 19 casos.

Método: Realizamos uma avalia- ção clínica, radiológica e bioquímica, incluindo estudos enzimáticos, que nos permitiram estabelecer o diagnóstico definitivo em 19 casos.

Resultados: Nem todos os pacientes apresentaram níveis elevados de GAG na urina, devendo os ensaios enzimáticos serem realizados em todos os pacientes com forte suspeita clínica. O diagnóstico foi estabelecido em média aos 48 meses de idade e os casos, após amplo estudo clínico, radiológico e bioquímico, foram classificados como: Hurler - MPS I (1 caso);
Hunter - MPS II (2 casos); Sanfilippo - MPS III (2 casos); Morquio - MPS IV (4 casos); Maroteaux-Lamy - MPS VI (9 casos); e Sly - MPS VI (1 caso).

Discussão: A proporção relativamente alta de MPS VI (MaroteauxLamy) contrasta com a maioria dos dados da literatura e pode expressar uma variabilidade populacional.

DESCRITORES: Mucopolissacaridoses. Glicosaminoglicanos. Doenças lisossômicas de depósito. 


\section{REFERENCES}

1. WHITLEY CB - The mucopolysaccharidoses. In: BEIGHTON P McKusick's Heritable disorders of connective tissue. $5^{\text {th }}$ ed., St Louis, Mosby, 1993. p367-499.

2. NEUFELD EF \& MUENZER J - The mucopolysaccharidoses. In: SCRIVER CR, BEAUDET AL, SLY WS et. al. - The metabolic and molecular bases of inherited diseases. $7^{\text {th }}$ ed. New York, McGraw-Hill, 1995. p.2465-2494.

3. LEISTNER $\mathrm{S} \&$ GIUGLIANI R - A useful routine for biochemical detection and diagnosis of mucopolysaccharidoses. Gen Mol Biol 1998; 21:163-167.

4. LOWRY RB \& RENWICK DHG - Relative frequency of the Hurler and Hunter syndromes (letter). N Engl J Med 1971; 284:221-222.

5. SCHAAP T \& BACH G - Incidence of mucopolysaccharidoses in Israel: is Hunter disease a Jewish disease? Human Genet 1980; 56:221226.

6. YOUNG ID \& HUNTER PS - Incidence of Hunter's syndrome. Human Genet 1982; 60:391-392.
7. HOPWOOD JJ \& MORRIS CP - The mucopolysaccharidoses: diagnosis, molecular genetics and treatment. Mol Biol Med 1990; 7:381-404.

8. LOWRY RB, APPLEGARTH DA, TOONE JR et al. - An update on the frequency of mucopolysaccharide syndromes in British Columbia. Hum Genet 1990; 85:389

9. NELSON J - Incidence of the mucopolysaccharidoses in northern Ireland. Hum Genet 1997; 101:355-358.

10. GIUGLIANI R, DUTRA JC, BARTH ML et al. - Seven-year experience of a reference laboratory for the detection of inborn errors of metabolism in Brazil. J Inher Metab Dis 1991; 14:400-402.

11. COELHO JC, WAJNER M, BURIN M et al. - Selective screening of 10,000 high-risk Brazilian patients for the detection of inborn errors of metabolism. Eur J Pediatr 1997; 156:650-654.

Received for publication on the 22/09/00 